DRUŠ. ISTRAŽ. ZAGREB

GOD. 30 (2021)

BR. 3,

STR. 637-645 https://doi.org/10.5559/di.30.3.11

\section{Gina Riley UNSCHOOLING: EXPLORING LEARNING BEYOND THE CLASSROOM}

Palgrave Macmillan, Cham, 2020., 159 str.

U osvit promjene načina te oblika učenja i poučavanja u svijetu pod utjecajem prije svega pandemije COVID-19, izdavačka kuća Palgrave Macmillan u okviru serije Palgrave studije alternativnog obrazovanja objavila je u srpnju 2020. godine prvo izdanje knjige Unschooling: istraživanje učenja izvan učionice (Unschooling: Exploring Learning Beyond the Classroom) školske i kliničke psihologinje te voditeljice programa podrške adolescentskog inkluzivnog obrazovanja na Sveučilištu u New Yorku, Gine Riley.

U uvodnom dijelu knjige autorica opisuje osobna iskustva istraživanja perspektive unschoolinga, uspoređujući ih s vještinama učenja i poučavanja u osnovnoškolskom, srednjoškolskom te visokoškolskom obrazovanju.

U drugom poglavlju autorica prikazuje povijesni razvoj unschooling koncepta. Navodi glavne značajke ovog oblika školovanja u kući, a koji se prema njezinu mišljenju temelji na iskustvenom učenju te autonomiji učenika. U prilog tome autorica prikazuje utjecaje francuskoga prosvjetitelja Rousseaua, američkoga progresivista Deweya, Engleza Neilla (osnivača Summerhill škole), hrvatskoga filozofa Illicha te američkih učitelja Holta i Gattoa na stvaranje, razvoj i kreiranje unschooling pristupa.
Treće poglavlje upućuje na neke teorijske pristupe unschooling perspektive učenja i poučavanja. Autorica naglašava važnost teorije samoodređenja i kognitivne evaluacije, privrženosti te višestruke inteligencije. Teorija samoodređenja i kognitivne evaluacije govori o povezanosti intrinzične motivacije, kompetencija te autonomije učenika $u$ učenju i poučavanja nastavnih sadržaja. S druge strane, teorija privrženosti upućuje na povezanost intrinzične motivacije, pružanja roditeljske podrške u djetetovu razvoju i u usvajanju znanja i vještina tijekom unschooling učenja. Suprotno tome, prepoznatljiva Garnerova teorija višestruke inteligencije ističe igru kao jedan od oblika učenja i poučavanja učenika u okviru unschooling perspektive, uzimajući u obzir različitosti sposobnosti i mogućnosti učenika u određenim vještinama.

U četvrtom poglavlju autorica promatra demografske, zakonodavne, iskustvene, kulturne, jezične, vjerske, etničke i rasne utjecaje na razvoj perspektive unschoolinga, kao i školovanja od kuće. U tom pogledu ona naglašava nužnost suradnje roditelja i školske ustanove $u$ načinu $\mathrm{i}$ obliku izvještavanja o odgojno-obrazovnim dostignućima učenika. Također napominje kako se motivacija i interes roditelja za ovakav oblik učenja i poučavanja javlja prije svega zbog nezadovoljstva školskim uspjehom, poteškoćama prilagodbe djeteta školskoj i razrednoj sredini, kao i zbog raznih religijskih razloga. Isto tako autorica upozorava na odluku roditelja o školovanju prema unschooling pristupu, ponajviše, zbog različitih oblika diskriminacije, nasilja i zlostavljanja prema učenicima latinskoameričkoga te afroameričkoga podrijetla te LGBT učenika.

U petom poglavlju autorica govori o nekim oblicima unschoolinga, a to su školovanje od kuće, unschooling te radikalni unschooling. Prema njezinu mišljenju, školovanje od kuće temelji se na istraživačkom učenju i poučavanju učenika koji ujedno preuzima odgovornost za svoja obrazovna dostignuća uz roditeljsko vodstvo i podršku. S druge strane, $\mathrm{u}$ radikalnom 
DRUŠ. ISTRAŽ. ZAGREB

GOD. 30 (2021),

BR. 3,

STR. 637-645

unschoolingu učenik ima neograničenu autonomiju u učenju i stjecanju znanja. Ovaj pristup ne poznaje didaktičko-metodičku organizaciju nastavnoga procesa, nego učenik u suradnji sa svojim roditeljima bira način, oblik te stil stjecanja vještina i znanja. Jednako tako, autorica upućuje na daljnji napredak i razvoj ove perspektive u okviru američkoga odgojno-obrazovnog sustava te kritičke stavove znanstvenika i istraživača oko toga.

U šestom poglavlju autorica obrazlaže neke čimbenike koji utječu na roditeljsku odluku o početku školovanja svojega djeteta u skladu s perspektivom unschoolinga. Vrlo važan aspekt u tome imaju negativni stavovi roditelja prema školi, kao i nemogućnost prilagodbe djeteta na školsko i razredno ozračje, a što kao posljedicu ima razne oblike nasilja, verbalno vrijeđanje i zadirkivanje učenika. Osim toga, utjecaj na roditeljske stavove ima relevantna pedagogijska literatura, posebice ona istraživača i znanstvenika koji se bave navedenom problematikom. Jednako tako, roditelji prihvaćaju ovakav oblik učenja i poučavanje na temelju iskustava drugih roditelja ili pak informacija koje dobivaju na nekim znanstvenim tribinama ili diskusijama. S druge strane, majke svoju odluku o promjeni načina školovanja temelje na teoriji privrženosti i pružanja podrške razvoju djeteta u skladu s perspektivom unschoolinga. Međutim, autorica pritom naglašava kako je potrebno uzeti u obzir proces prilagodbe na ovakav oblik učenja te djetetu omogućiti prilagodbu na novu organizaciju rada.

U sedmom poglavlju autorica istražuje učinkovitost učenja i poučavanja unschooling koncepta. Naime, ona uspoređuje različitosti stjecanja obrazovnih dostignuća u školskoj ustanovi te perspektivi unschoolinga na području čitanja, pisanja i računanja, društveno-humanističkog te STEM područja. U tome pogledu dolazi do zaključka kako učenici koji uče po modelu unschoolinga pokazuju slabiji školski uspjeh $\mathrm{u}$ odnosu na one iz redovitih odgojno-obrazovnih ustanova ili pak učenike koji se školuju od kuće prema standardiziranom kurikulu.

Autorica $\mathrm{u}$ osmom poglavlju istražuje neke izazove i poteškoće roditelja koji svoju djecu poučavaju prema unschooling perspektivi. Ona naglašava kako su navedeni roditelji vrlo često žrtve predrasuda i stereotipa okoline, a što ima za posljedicu narušavanje djetetova prava na odgoj i obrazovanje. Izazov zaposlenim i samohranim roditeljima može predstavljati način organizacije djetetova vremena $u$ ova$\mathrm{kvu}$ obliku nastave. Jednako tako, poteškoću učeniku i roditelju može stvarati izostanak stvaranja socijalnih odnosa među vršnjacima te drugim roditeljima, a koje je moguće ostvariti jedino u okviru školskog ozračja. Međutim, autorica naglašava kako učenici s poteškoćama u razvoju te socioemocionalnim poremećajima koji nastavu pohađaju u okviru koncepta unschoolinga imaju više motivacije, samopouzdanja te bolju povezanost sa svojim roditeljima, kao i autonomiju u kreiranju svojega rasporeda učenja i poučavanja od onih koji pohađaju školsku ustanovu.

U devetom poglavlju autorica proučava iskustva prema unschooling perspektivi. Ona, naime, kroz stavove odraslih propitkuje prednosti i nedostatke unschoolinga, socijalizaciju i stjecanje vršnjačkih odnosa, prilagodbu na fakultetsko obrazovanje te ostvarivanje financijske neovisnosti. U tom pogledu ona iznosi osobno iskustvo svojega sina glazbenika Benjamina Rileya, kojeg je poučavala prema modelu unschoolinga.

U desetom poglavlju autorica objašnjava modele i oblike unschooling perspektive $\mathrm{u}$ odgoju i obrazovanju. Upućuje na koncept worldschoolersa, odnosno djece putnika čiji se način i oblik školovanja temelji na stjecanju znanja i vještina putovanjem u razne krajeve i prostore svijeta. Isto tako autorica nas upoznaje s pristupom škole $u$ prirodi, gdje se učenje i poučavanje ne odvija u prostoru učionice ne- 
go u svakodnevnom okruženju djeteta. Govori se i o tzv. hackschoolingu, kojim se promiče važnost mentalnoga zdravlja učenika, njihovih interesa i motivacije za učenje. Međutim, unatoč motivaciji i interesima za poučavanje prema unschooling perspektivi, nemaju svi roditelji mogućnosti kao ni uvjete za njezino ostvarivanje. Prema tome, može se govoriti o unschooling zajednici u okviru koje se učenicima i roditeljima pruža podrška i pomoć za ostvarivanje njihovih namjera.

$\mathrm{U}$ jedanaestom poglavlju autorica se osvrće na futurološku perspektivu unschooling koncepta. Smatra kako je u okviru reforme školstva potrebno uzeti u obzir različitosti načina, oblika učenja i poučavanja učenika, njihove socioemocionalne karakteristike te različite pristupe vrednovanju obrazovnih dostignuća. U tom pogledu ona navodi projektno istraživačko učenje, koje osim u okviru unschooling koncepta ima važnu ulogu i u budućim promjenama odgoja i obrazovanja.

Zaključno, knjiga Unschooling: istraživanje učenja izvan učionice daje suvremeniji pogled na odgoj i obrazovanje djece, a koje se ovom pandemijom koronavirusa uvelike počelo mijenjati. Autorica u tom pogledu preporučuje perspektivu unschoolinga, koja ne prihvaća didaktičko-metodičku organizaciju nastavnoga procesa, nego se zasniva na iskustvenom, projektno istraživačkom i cjeloživotnom učenju te $u$ autonomiji učenika u izboru sadržaja, metoda i oblika rada, kao i načina vrednovanja.

Knjiga je prikladna za teoretičare i znanstvenike koji se bave školskom pedagogijom i didaktikom, prije svega zbog svoje inovativnosti i stručnosti u prikazu drukčijeg oblika učenja i poučavanja, što ga je autorica primjenjivala i $u$ vlastitoj odgojno-obrazovnoj praksi. 